\title{
A Study on Constraints Perceived by Layer Farmers of Uttar Pradesh State
}

\author{
Maina Kumari $^{1 *}$, M. P. Sagar ${ }^{2}$ and Kamlesh Kumar Dhawal ${ }^{1}$ \\ ${ }^{1}$ Department of Veterinary and Animal Husbandry Extension Education, Apollo College of \\ Veterinary Medicine, Jaipur (Rajasthan) \\ ${ }^{2}$ Central Avian Research Institute, Izatnagar (Uttar Pradesh) \\ *Corresponding author
}

\section{A B S T R A C T}

\begin{tabular}{|l|}
\hline Ke y w o r d s \\
Layer, Trainee, \\
$\begin{array}{l}\text { Non-trainee, } \\
\text { Adopter, } \\
\text { Constraints, Uttar } \\
\text { Pradesh }\end{array}$ \\
\hline Article Info \\
\hline $\begin{array}{l}\text { Accepted: } \\
\text { 20December } 2020 \\
\text { Available Online: } \\
\text { 10January 2021 }\end{array}$ \\
\hline
\end{tabular}

The present study was conducted to assess the various constraints perceived by layer farmers and accountable factors for non-adoption of layer farming by trainees of Uttar Pradesh state. A comparative study was conducted between the trainee and non-trainee farmers of same agro-climatic zones in which 54 were trainee and 54 were non-trainee farmers. Out of 54 trainees only 30 farmers had adopted the layer farming. So, in case of constraints perceived by layer farmers, a comparison of 30 trainee farmers was done with 54 non-trainee farmers and total sample size was reduced to 84 only and accountable factors for non-adoption of layer farming were considered for 24 trainee farmers. Data were collected through structured mailed questionnaire and telephonic survey. The seriousness of constraints was measured through Garrett Ranking and expressed in terms of rank. Data analysis elicited that high price of feed grains was prime constraint in layer farming with respective mean score of 76.23 and 75.48 for trainee and non-trainee layer farmers, followed by high fluctuation of egg price (MS 74.76 and 70.33). In case of nonadoption of layer farming, lack of money for opening farm was the $1^{\text {st }}$ major reason which compelled trainee farmers to avoid layer farming with mean score of 74.91. Insufficient land (MS 72.25) was ranked $2^{\text {nd }}$, followed by lack of confidence and courage for opening farm (MS 56.62) with rank third. So, to overcome these constraints the Govt. should subsidize the feed mill equipment to lower the cost of feed and also fix a reasonable price for eggs.

\section{Introduction}

The poultry industry is one of the profitable agro industries which can effectively tackle the problems of unemployment and underemployment in the rural areas, particularly for small and marginal farmers. Layer industry can be adopted under a wide range of climatic conditions and can generally be combined conveniently with other farm enterprises like fisheries and goattery (Pawariya and Jheeba, 2015). The Indian poultry sector with 16.80 per cent growth in poultry population, has witnessed one of the fastest annual growth of 6-8 per cent in production over the last decade amongst all animal-based sectors. (Anonymous, 2018). Rapid growth of poultry industry has been 
encouraging many farmers to adopt poultry farming as a main source of income. Poultry production as an aspect of livestock production is important to the biological needs, economic and social development of the people in any nation (Tsado, et al., 2017; Aromolaran, et al., 2013). The poultry industry is a growing business in these recent years. The demand for its egg, meat and chicken is increasing at an enthusiastic rate. Poultry farming has been one of the important means to alleviate poverty, reduce malnutrition and unemployment among both rural and urban people. Constant efforts made in up-gradation, modification and application of new technologies paved the way for the multifold and multifaceted growth in poultry and allied sectors. The development is not only in size but also in productivity, sophistication and quality.

In spite of the fact that poultry industry not been able to surpass the requirement. To meet the demand through commercialization, people have suffered different challenges like increasing cost of production, lack of biosecurity maintenance, improper housing maintenance, lack of proper knowledge about poultry production, market/price fluctuation, high cost of energy, high mortality rate and there are various hindrances in trade, marketing, health, quality sanitation, management causing the production inefficient. Such challenges are threatening day by day, causing the poultry business at risk. (Dhakal et al., 2019). Even if the poultry number is high, the farmers do not benefit from this sector, because of traditional production system, predator challenge, disease prevalence, feed shortage and poor management practices (Malkamu and Wube, 2013). The poultry industry at present is handicapped on account of high feed cost (more than 75 percent of total cost of production). The high cost of feed and treatment has its share since production of raw ingredients especially the maize sustains only $40-50 \%$ of demand for feed production (Razzaq et al., 2011). Over the last few decades, successive governments have encouraged the development of modern poultry enterprises with a resultant sudden rush of people of diverse backgrounds into the industry. This has resulted in the development of an unplanned and unregulated industry with numerous attendant problems (Okoli, et al., 2004).

Determination of these constraints could be useful in enhancing productivity. Therefore, the objective of the study was to find out the different constraints being faced by layer farmers and also determined the factor responsible for non-adoption of layer farming by trainees of Uttar Pradesh state.

\section{Materials and Methods}

Sampling procedure: Two types of respondents were selected for the study i.e., trainee and non-trainee farmers.

Selection of trainees: A list of farmers who had received specialized layer farming training from CARI during last five year (2013-14 to 2017-18) was obtained from officials and from this list, the trainees who belong to UP state were selected as respondents. The respondents (trainee farmers) were belonging to 5 agro-climatic zones out of 9 agro-climatic zones. Thus, a total of 54 trainee farmers were selected for the study.

Selection of non-trainees: A comprehensive list of non-trainee layer farmers scattered in the state was prepared in consultation with scientists of CARI, C.V.O of different districts of layer farming dominated area, poultry farmers and private input dealers. An equal number of non-trainee layer farmers were also purposively selected from this list. 
Respondents were selected from same agroclimatic zone for the purpose of comparison. A comparative study was conducted between these trainees and non-trainees. Thus, total sample size was 108 . Out of 54 trainees only 30 farmers had adopted the layer farming. So, in case of constraint perceived by farmers in layer farming, a comparison of 30 trainee layer farmers was done with 54 non-trainee layer farmers and total sample size was reduced to 84 . The factor responsible for nonadoption of layer farming was calculated only for 24 trainee farmers.

Constraints are the impediments those come in the way of achieving the desired outcome. Constraints in the present study were operationalized as the problems encountered by the farmers in layer farming, reasons for non-adoption of layer farming. The constraints were documented through a structured mailed questionnaire. The analysis of responses was done through Garrett Ranking and expressed in terms of rank. The respondents were asked to give the ranks to the factors given. The order of merit, assigned by them was converted into ranks by using the formula:

Percent position $=\frac{100(\text { Rij-0.5) }}{\mathrm{Nj}}$

where,

Rij $=$ rank given for $\mathrm{i}^{\text {th }}$ factor by ${ }^{\text {jth }}$ individual $\mathrm{Nj}=$ number of factors ranked by the $\mathrm{j}^{\text {th }}$ individual.

With the help of Garrett's Table, the percent position calculated was converted into scores. Then for each factor, the scores of everyone are summed up and then total value of scores and mean values of score were estimated. The mean scores for all the factors were arranged in order of merit and inference were drawn. The factors having highest mean value was considered to be the most important factor.

\section{Various constraints perceived by trainee and non-trainee layer farmers}

The data presented in table 2 indicates that for trainee and non-trainee farmers, high price of feed grains was biggest constraint in layer farming with respective mean score of 76.23 and 75.48. The $2^{\text {nd }}$ major constraint was high fluctuation of egg price (MS 74.76 and 70.33) for trainee and non-trainee layer farmers, respectively. For trainee layer farmers $3^{\text {rd }}$ serious constraint was absence of insurance policy for poultry (MS 60.83), while for nontrainees next serious constraint was lacking veterinary services when needed (MS 69.61). Other constraints for trainees were lacking veterinary services (MS 60.16), high interest rate on loan (MS 50.00), temperature instability in summer (MS 49.86), highly competitive market (MS 42.00), high mortality rate of birds (MS 31.20), manure disposal (MS 26.20) and less production due to improper management (MS 25.66) with ranks $4^{\text {th }}, 5^{\text {th }}, 6^{\text {th }}, 7^{\text {th }}, 8^{\text {th }}, 9^{\text {th }}$ and $10^{\text {th }}$, respectively. For non-trainee layer farmers lacking insurance policy (MS 58.00), temperature instability in summer (MS 50.29), high interest rate on loan (MS 49.70), high mortality rate of birds (MS 42.00), highly competitive market (MS 37.00), less production due to improper management (MS 24.33) and manure disposal (MS 21.66) were the very next serious constraints with ranks $4^{\text {th }}, 5^{\text {th }}, 6^{\text {th }}, 7^{\text {th }}, 8^{\text {th }}, 9^{\text {th }}$ and $10^{\text {th }}$, respectively.

These finding shows the almost similar behavior of the trainee and non-trainee for the constraints being faced. However, constraints related with farm insurance and loan were more serious to the trainee than non-trainee. This might be due to that most of the trainees started poultry farming, were belonged to middle-class family and most of the nontrainee had layer farming as traditional 
occupation. Overall, high price of feed grains as the $1^{\text {st }}$ major constraint which accounted for mean score of 75.12. The $2^{\text {nd }}$ major constraint was high fluctuation of egg price (MS 73.22). Lack of veterinary facility when required (MS 64.88) ranked $3^{\text {rd }}$ followed by no insurance policy for poultry (MS 59.41). The other minor constraints were temperature maintenance (MS 50.07), high interest rate on loan (MS 49.85), highly competitive market (MS 39.50), high mortality rate of birds (MS
36.60), less production due to improper management (MS 24.99) and manure disposal (MS 23.93) and ranked $5^{\text {th }}, 6^{\text {th }}, 7^{\text {th }}, 8^{\text {th }}, 9^{\text {th }}$ and $10^{\text {th }}$, respectively. These finding got support from Thorat (2005) who reported the constraints of the poultry entrepreneurs viz; low egg price during the summer, costly birds, high feed cost, high rate of interest on loan, difficulty in getting loan, low wholesale price of eggs, high charge of electricity and risk \& uncertainty in poultry enterprise.

Table.1 Percentage position and their corresponding Garrett's table value

\begin{tabular}{|c|c|c|c|}
\hline Rank & \multicolumn{2}{|c|}{ Percentage Position } & Garrett's Table Val \\
\hline $\mathbf{1 .}$ & $100(1-0.5) / 10$ & $=5$ & 82 \\
\hline $\mathbf{2 .}$ & $100(2-0.5) / 10$ & $=15$ & 71 \\
\hline $\mathbf{3 .}$ & $100(3-0.5) / 10$ & $=25$ & 64 \\
\hline $\mathbf{4 .}$ & $100(4-0.5) / 10$ & $=35$ & 58 \\
\hline $\mathbf{5 .}$ & $100(5-0.5) / 10$ & $=45$ & 53 \\
\hline $\mathbf{6 .}$ & $100(6-0.5) / 10$ & $=55$ & 48 \\
\hline $\mathbf{7 .}$ & $100(7-0.5) / 10$ & $=65$ & 43 \\
\hline $\mathbf{8 .}$ & $100(8-0.5) / 10$ & $=75$ & 37 \\
\hline $\mathbf{9 .}$ & $100(9-0.5) / 10$ & $=85$ & 30 \\
\hline $\mathbf{1 0 .}$ & $100(10-0.5) / 10$ & $=95$ & 19 \\
\hline
\end{tabular}

Table.2 Constraints perceived by trainee and non-trainee layer farmers

\begin{tabular}{|l|l|l|l|l|l|l|}
\hline \multirow{2}{*}{ Constraints } & \multicolumn{2}{l|}{ Trainees $\mathbf{( n = 3 0 )}$} & \multicolumn{2}{l|}{$\begin{array}{l}\text { Non-trainees } \\
(\mathbf{n = 5 4 )}\end{array}$} & \multicolumn{2}{l|}{ Pooled (n=84) } \\
\cline { 2 - 7 } & $\begin{array}{l}\text { Mean } \\
\text { score }\end{array}$ & Rank & $\begin{array}{l}\text { Mean } \\
\text { score }\end{array}$ & Rank & $\begin{array}{l}\text { Mean } \\
\text { Score }\end{array}$ & Rank \\
\hline High price of feed grains & 76.23 & I & 75.48 & I & 75.12 & I \\
\hline High fluctuation of price in eggs & 74.76 & II & 70.33 & II & 73.22 & II \\
\hline No insurance policy for poultry & 60.83 & III & 58.00 & IV & 59.41 & IV \\
\hline $\begin{array}{l}\text { Lack of veterinary facility when } \\
\text { required }\end{array}$ & 60.16 & IV & 69.61 & III & 64.88 & III \\
\hline High interest rate on loan & 50.00 & V & 49.70 & VI & 49.85 & VI \\
\hline High mortality rate of birds & 31.20 & VIII & 42.00 & VII & 36.60 & VIII \\
\hline Temperature maintenance & 49.86 & VI & 50.29 & V & 50.07 & V \\
\hline Highly competitive market & 42.00 & VII & 37.00 & VIII & 39.50 & VII \\
\hline Manure disposal & 26.20 & IX & 21.66 & X & 23.93 & X \\
\hline $\begin{array}{l}\text { Less production due to improper } \\
\text { management }\end{array}$ & 25.66 & X & 24.33 & IX & 24.99 & IX \\
\hline
\end{tabular}


Table.3 Accountable factors for non-adoption of layer farming by trainee farmers

\begin{tabular}{|l|l|l|}
\hline \multicolumn{1}{|c|}{ Factors } & Mean score & Rank \\
\hline Lack of money for opening farm & 74.91 & I \\
\hline Insufficient land & 72.25 & II \\
\hline Lack of confidence and courage for opening farm & 56.62 & III \\
\hline High insecurities like no bird's insurance & 55.25 & IV \\
\hline Unsuitable location of land & 52.91 & V \\
\hline High risk in layer farming due to long production cycle & 37.70 & VII \\
\hline No family supports & 52.12 & VI \\
\hline Lack of proper marketing channels & 27.83 & IX \\
\hline Don't have enough time due to business or job & 37.08 & VIII \\
\hline
\end{tabular}

Accountable factors for non-adoption of layer farming by trainee layer farmers

The factors responsible for non-adoption of layer farming were concluded and ranked by using Garret Ranking. The data given in table 3 pointed out lack of money for opening farm (MS 74.91) was the first major reason which compelled them to avoid layer farming. Insufficient land (MS 72.25) was ranked second, followed by lack of confidence and courage for opening farm (MS 56.62) with rank third and high insecurity (MS 55.25) ranked fourth. The first four factors indicated that most of the trainees had middle-class background which was major reason for insufficient capital amount, small land size and inability to take risk. The other minor reasons were unsuitable land position (MS 52.91), no family support (MS 52.12), high risk in layer farming (MS 37.70), don't have enough time due to business or job (MS 37.08), and lack of proper marketing channels (MS 27.83). These factors are primarily concerning about the government and their policies and organized or unorganized poultry sector. These can be ruled out with the help of govt. and stakeholder as well as collaboration of both of these.

In conclusion the severity of the constraints faced in layer farming varied from trainee and non-trainee layer farmers. However, the most severe constraints faced were high price of feed grain, high fluctuation of price in eggs, lack of veterinary facility when required and no insurance policy for poultry. However, poor or middle-class status of trainee became major hindrance to adopt layer farming as entrepreneurship.

Based on the study findings, it is recommended that:

Government can encourage farmers to establish own feed mill by availing subsidy on feed mill equipment to prepare low cost feed for different types of poultry stock.

Egg price should be at reasonable price like MSP for other commodities. So, that poultry farmer should get a marginal profit over egg production.

The Government should recruit more veterinary technicians and doctors specialized in poultry field to proffer solutions to many of the constraints faced by poultry farmers as regards diseases control and timely avail veterinary services.

Capacity training of poultry farmers to enable them to cope with the challenges of modern poultry farming and commercialization of layer production should be carried out.

5. Extension agents should work more with 
poultry farmers in facilitation of credit agencies such as bank of agriculture to the poultry farmers to access farm credits needed to purchase necessary poultry equipment and medications required to overcome their constraints and enjoy optimal poultry production benefits.

Government should tackle the problem of loan/credit procurement, market price instability, disease and pest as well as proper funding of small-scale layer business so as to enhance the commercialization of poultry industry in India.

\section{References}

Anonymous. 2018. Annual report 2017-2018, Department of animal husbandry and dairying \& fishery (DAHD \&F), Govt. of India.

Aromolaran, A. K., Ademiluyi, I.O. and Itebu, O. J. 2013. Challenges of small poultry farms in layer production in Ibadan Oyo state Nigeria. Global Journal of Science Frontier Research Agriculture and Veterinary Sciences, 13(2): 5-10.

Dhakal, R., Joshi, B., Karn, R., Bhusal, S. and Acharya, B. 2019. Scenario, Challenges and Prospects of Poultry Production in Nepal. Acta Scientific Veterinary Sciences, 1(1): 16-20.

Melkamu, B.Y and Wube, A. 2013. Constraints and Opportunities of
Village Chicken Production in Debsan TiKara Keble at Gonder Zuria Woreda, North Gonder, Ethiopia. International Journal of Scientific and Research Publications, 3(9).

Okoli, I. C., Anyaegbunam, C. N., Etuk, E. B., Opara, M. N. and Udedibie, A. B. I. 2005. Entrepreneurial characteristics and constraints of poultry enterprises in Imo state, Nigeria Journal of agriculture and social research, 5(1):25-32.

Pawariya, V. and Jheeba, S. 2015. Economic analysis of costs-return, income and employment in poultry enterprise in Jaipur district of Rajasthan state. International journal of agricultural science and research, 5(1):73-80.

Razzaq, A., Ali, T., Saghir, A., Arshad, S. and Cheema, A. 2011. Training needs assessment of poultry farmers in Tehsil Faisalabad. The Journal of Animal \& Plant Sciences, 21(3):629-631.

Thorat, G.N. 2005. An analysis of poultry entrepreneur's knowledge about poultry management practices. thesis, M.Sc. Sardar Krushinagar Dantiwada Agriculture University, Palanpur, Gujarat.

Tsado, J. H., Adeniji. O. B., Tyabo, I. S., Kolo, E. S and Omofuma, A. E. 2017. Constraints to poultry production among farmers in Niger state, Nigeria. FUOYE Journal of Agriculture and Human Ecology, 1(2): 75-83.

\section{How to cite this article:}

Maina Kumari, M. P. Sagar and Kamlesh Kumar Dhawal. 2021. A Study on Constraints Perceived by Layer Farmers of Uttar Pradesh State. Int.J.Curr.Microbiol.App.Sci. 10(01): 3088-3093. doi: https://doi.org/10.20546/ijcmas.2021.1001.359 